\title{
The role of orexin in post-stroke inflammation, cognitive decline, and depression
}

\author{
Juhyun Song ${ }^{1}$, Eosu Kim ${ }^{4}$, Chul-Hoon Kim³ ${ }^{3}$ Ho-Taek Song ${ }^{5}$ and Jong Eun Lee ${ }^{1,2^{*}}$
}

\begin{abstract}
Ischemic stroke results in diverse pathophysiologies, including cerebral inflammation, neuronal loss, cognitive dysfunction, and depression. Studies aimed at identifying therapeutic solutions to alleviate these outcomes are important due to the increase in the number of stroke patients annually. Recently, many studies have reported that orexin, commonly known as a neuropeptide regulator of sleep/wakefulness and appetite, is associated with neuronal cell apoptosis, memory function, and depressive symptoms. Here, we briefly summarize recent studies regarding the role and future perspectives of orexin in post-ischemic stroke. This review advances our understanding of the role of orexin in post-stroke pathologies, focusing on its possible function as a therapeutic regulator in the post-ischemic brain. Ultimately, we suggest the clinical potential of orexin to regulate post-stroke pathologies.
\end{abstract}

Keywords: Post-stroke, Orexin, Inflammation, Cognitive dysfunction, Depression

\section{Introduction}

Ischemia resulting from a disturbance of cerebral blood flow is one of the leading causes of morbidity and mortality worldwide, resulting in permanent disability $[1,2]$. The prevalence of stroke was estimated almost 5.7 million people in $2005[2,3]$ and was expected the increase of prevalence in the future according to global researches [4-6]. Stroke is related to several diseases, including hypertension, dyslipidemia, and obesity $[7,8]$. Recently, stroke has emerged as a direct cause of dementia [9]. Some stroke patients are diagnosed with dementia or show cognitive decline [10]. Additionally, new-onset dementia occurs in $5.4 \%$ of patients older than 60 years and $10.4 \%$ of patients older than 90 years 1 year after a stroke [11]. Furthermore, several studies indicate a strong relationship between stroke and depression [12-14]. Several studies also report that the prevalence of post-stroke depression is more than $22.5 \%$ $[13,14]$. Orexin peptides (orexin-A and orexin-B) produced by the lateral hypothalamus are known to regulate feeding, energy homeostasis, neuroendocrine activities, and the sleep-wake cycle by binding to orexin-1 (OX1R)

\footnotetext{
* Correspondence: jelee@yuhs.ac

${ }^{1}$ Department of Anatomy, Yonsei University College of Medicine, Seoul 120-752, South Korea

${ }^{2}$ BK21 Plus Project for Medical Sciences, and Brain Research Institute, Yonsei University, College of Medicine, Seoul 120-752, South Korea

Full list of author information is available at the end of the article
}

and orexin-2 (OX2R) receptors [15-18]. OX1R is commonly present in the tenia tecta, dorsal raphe nucleus and Cornu Ammonis (CA)1, CA2, indusium griseum, septohippocampal nucleus in brain $[19,20]$. OX2R is abundant in brain regions related to basal ganglia such as the ventral striatum and subthalamic nucleus [19,21-23]. Some studies have elucidated the role of orexin in blood pressure regulation [24], inflammation [25], memory function [26,27], and depression [28]. In this review, we highlight recent studies regarding the role of orexin in the brain following ischemic stroke, particularly emphasizing studies on the role of orexin in inflammation, cognitive dysfunction, and depression following post-ischemic stroke.

\section{Post-ischemic stroke Inflammation following a stroke}

Ischemic stroke results in inflammation in the brain, which can directly influence the repair of neural damage and subsequent pathologies [29]. Inflammation is commonly regarded as necessary for the clearance of the large amount of debris caused by brain cell necrotic death [30,31]. After a stroke, cerebral inflammation exacerbates vascular dysfunction and leads to severe neuronal cell death [32]. Post-ischemic inflammation, which is a crucial process in the pathophysiology of ischemic stroke, is associated with post-stroke prognosis 
[29,30,32-35]. The distinct features of ischemic stroke are not only a large amount of necrotic neuronal death but also extreme infiltration of immune cells $[29,30]$. After the mild middle cerebral artery occlusion, cytochrome- $\mathrm{C}$ release and caspase processing are observed at 6 and 9 hour, and cell death are reported the severe inflammation of post-ischemic stroke between 24 and 72 hour [29,32]. Severe inflammation results in secondary brain damage [36] such as cerebral swelling (i.e., brain edema), which is often fatal in ischemic stroke patients $[29,30]$. Modulation of the inflammatory response after a stroke is important due to the direct association between inflammation and secondary damage following a stroke.

\section{Cognitive impairment following a stroke}

According to recent studies, stroke is an emerging risk factor for dementia [37]. A previous study identified dementia after a stroke as vascular dementia [38]. However, a recent study used the term post-stroke dementia (PSD) to define any dementia occurring after a stroke [39]. PSD includes all dementias occurring after a stroke, including vascular dementia, Alzheimer's disease (AD), and mixed dementia (vascular dementia with $\mathrm{AD}$ ) $[39,40]$. Dementia is associated with neuronal dysfunction and neuronal death, causing cognitive impairment [41]. Approximately $30 \%$ of stroke patients suffer cognitive impairment after a stroke [42] and develop dementia within 1 year of stroke onset [43]. Some clinical studies also report the presence of AD-related pathogenesis in one-third of dementia cases after a stroke [44]. According to recent studies, a high proportion of stroke patients exhibit cognitive impairment within 3 months after a stroke [45], and $47.3 \%$ of first-stroke patients show memory loss 3 month after a stroke [46]. Therefore, several studies have continued to search for therapeutic solutions for PSD. One study utilizing a middle cerebral artery occlusion (MCAO) animal model suggests that reduced activity of extracellular regulated protein kinase (ERK) in the bilateral hippocampi may contribute to cognitive impairment after ischemic stroke [47]. Another study focused on a novel neurotransmitter that could decrease hippocampal neuronal damage and thereby alleviate cognitive impairment after ischemic stroke [48].

\section{Depression}

Depression following ischemic stroke is termed poststroke depression and is considered the most frequently observed psychiatric problem after cerebral ischemia [49]. A recent study reports that the prevalence of depression after a stroke ranges from $39 \%$ to $52 \%$ within 5 years following a stroke [12]. Post-stroke depression commonly occurs approximately 2 to 3 years following a stroke [50]. In the 1970s, the identification of depression following a stroke led to the concept that clinical depression after a stroke could be a consequence of brain damage [51,52]. A recent study reports that $33 \%$ of all stroke survivors show depressive symptoms based on research conducted between 1977 and 2002 [53]. In addition, clinical studies report that post-stroke depression could affect the recovery of function and cognitive ability [54-56]. One study reports that stroke patients who show improvements in cognitive function in the 3 months following the onset of a stroke show greater improvements in their levels of depression [57]. Poststroke depression is an important issue that it is linked to the progression of other stroke pathologies and could affect functional recovery after a stroke.

\section{Orexin}

The orexins, named for the Greek word for appetite [58], stimulate appetite [58] and are the common name given to the neuropeptide and the neurotransmitter [21] called orexin-A and orexin-B (also known as hypocretin-1 [HCRT-1] and hypocretin-2 [HCRT-2]) [58,59]. Orexins work by activating two G-protein-coupled receptors that are differentially expressed throughout the brain $[19,20]$, orexin receptor 1 (OXR1) and orexin receptor 2 (OXR2) (also named HCRTR1 and HCRTR2 [60]). Orexin-A has equal affinity for both OXR1 and OXR2 receptors, whereas orexin-B acts primarily on OX2R $[21,61,62]$. The activation of OX2R by orexin-A or -B opens nonselective cation channels to depolarize orexin neurons [63], and regulates the opening of $\mathrm{K}$ channels $[64,65]$, and promotes the release of presynaptic glutamate $[63,66]$, and gammaaminobutyric acid (GABA) [64]. Particularly, orexin-A rapidly crosses the blood-brain barrier (BBB) [67]. Orexins are produced by neurons mainly located in the lateral hypothalamic area $[58,68]$. These neurons send widespread projections into the prefrontal cortex, hippocampus, thalamus, and hypothalamus [69]. Orexin neurons also play crucial roles in the regulation of sleep and wakefulness [58,70,71], appetite [72-74], and energy homeostasis [75]. Orexin neurons detect nutritional status by reacting to peripheral metabolic signals such as glucose and appetite-related hormones (leptin and ghrelin) [76-78] and controlling the production glucose [79-81] and vital gases [82], and also receive the various neural signal inputs [83]. Moreover, orexin projected to cardiovascular regulatory centers in the hindbrain [21], and projected to the areas including locus coeruleus, raphe nuclei, parabrachial nuclei, central gray and nucleus tractus solitarius [69] which regulate peripheral blood pressure $[69,84,85]$. Several studies also show the cardiovascular effect of orexin through intracisternal and intrathecal injections of orexin- $\mathrm{A}$ and $-\mathrm{B}$ in the vasopressor area of the brain $[86,87]$. One study reports that orexin knock-out mice 
exhibit a reduced basal blood pressure response to motivated behavior [88]. In addition, the orexinergic system plays important roles in the regulation of depressionrelated neurophysiological processes, including cognitive processes $[89,90]$. The projection of orexinergic neurons to the hippocampus is implicated in learning and memory function $[26,27,91]$. Recent studies show that the nasal administration of orexin-A alleviates cognitive impairment in orexin/ataxin-3-transgenic mice [92]. Another clinical study demonstrates that lower orexin-A levels in cerebrospinal fluid are involved in learning and memory impairments caused by epilepsy [93]. Orexin levels in plasma and hypothalamus in brain were reduced in animal study [94] and orexin's concentration in serum and cerebrospinal fluid (CSF) also were low level in stroke patients [95]. Considering the results of these previous studies, orexins may play multiple roles by binding orexin receptors in diverse pathophysiologies after a stroke and the development of brain injury.

\section{The role of orexin in post-ischemic stroke The relationship between orexin and risk factors for a stroke}

Orexin is involved in blood pressure regulation [96,97]. Orexin knock-out mice and orexin neuron-ablated transgenic rats have lower basal blood pressure $[24,98]$. Additionally, the orexin system participates in the pathogenesis of high blood pressure in spontaneously hypertensive rats $[24,99]$. One study reported that the blockage of orexin receptors attenuates blood pressure in hypertensive rats [97]. In another in vivo study, the central administration of orexin in animals increases arterial blood pressure and heart rate, and these effects are attenuated by treatment with orexin receptor antagonists [100-104]. Intracerebroventricular injection of orexin-A increases arterial pressure in rats and rabbits $[85,105]$. One study demonstrated that intravenous administration of orexin decreases infarct volume by increasing cerebral blood flow [106]. Acute intracerebroventricular injection of orexin-B also increases arterial pressure [85]. Given that blood pressure is a risk factor for a stroke [107-109], the promotion of orexin secretion may be involved in the onset of stroke by regulating blood pressure.

\section{The role of orexin in inflammation after a stroke}

Several studies demonstrate that orexin-A inhibits apoptosis and lipid peroxidation in a hypothalamic cell model $[25,106,110]$. Another study reports that inflammation conditions induced by lipopolysaccharide administration lead to orexin neuron damage [111]. Recent studies highlighted the anti-inflammatory function of orexin in neuroinflammation diseases [112] and oxidative stress caused by cerebral ischemia [113]. In addition, orexin-A
mRNA level is decreased under acute inflammation conditions [114]. The cellular response to orexin receptor activation is increased intracellular $\mathrm{Ca}^{2+}$ influx by protein kinase $\mathrm{C}$-dependent activation or voltage-gated $\mathrm{Ca}^{2+}$ receptors $[115,116]$. The common downstream pathways of activated orexin receptors involve the activity of extracellular-signal-regulated kinases (ERK1/2) and p38 mitogen-activated phosphate kinase (MAPK) [116,117]. Tumor necrosis factor alpha (TNF- $\alpha$ ), a proinflammatory cytokine, impairs the function of the orexin system by decreasing levels of both prepro-hypocretin and OXR2 [118]. Moreover, intracerebroventricular administration of orexin-A before MCAO in rats $[119,120]$ and mice [110] reduces infarct size. Orexin-A alters intracellular metabolic function and cell survival in neuronal tissue and cells [110,120-122]. Recent studies show that orexin-A exerts neuroprotective effects, including the activation of hypoxia-inducible factor- $1 \alpha$ (HIF- $1 \alpha)$ and reduction of oxidative stress $[110,120]$. Orexin-A increases ATP via induction of the transcription factor HIF- $1 \alpha$ in mouse hypothalamic tissue under normoxic conditions [121]. Under ischemic conditions, orexin-A promotes the survival of primary cortical neurons in vitro and alleviates neuronal damage by modulating post-ischemic glucose intolerance in vivo $[110,121]$. In several clinical studies, a direct association between immunological problems [123-125] and orexin cell loss [126,127] is found in some narcolepsy patients. Indeed, narcolepsy patients exhibit elevated levels of TNF- $\alpha$, interleukin (IL)- 6 , and p75 in their blood [128]. In addition, recent study reported that orexin-A regulates infection-induced inflammation by modulating the IL- 6 and TNF- $\alpha$ in microglia and has protective role against ischemia stress [113]. Based on upper evidences, the elevation of orexin production may attenuate inflammation after a stroke and reduces the infarct size in brain.

\section{The role of orexin in cognitive impairment following a stroke}

Orexins play a positive role in learning and memory function, suggesting that they are directly associated with the arousal process $[26,129]$. Orexin and its receptors (OX1R and OX2R) are widely distributed throughout the brain and thereby regulate learning and memory functions $[26,27,91]$. Specifically, orexin-A enables the acquisition, consolidation, and retrieval of learning and memory in a passive avoidance task even in the presence of an over-production of beta amyloid [27,91,130]. To date, some studies indicate an emerging role of the orexin system in the avoidance test $[27,91,130]$ and Morris water maze test $[26,131]$. In detail, the inhibition of hippocampal OX1R using OX1R antagonism occurs in a deficit in cognitive processes based on the results of morris water maze task [131]. Also, the role of orexin-A 
demonstrated the contribution in the memory processing thorough T-maze footshock avoidance test and stepdown inhibitory avoidance [27]. Orexins could increase the release of corticotrophin-releasing hormone (CRH) as well as the circulating levels of adrenocorticotropic hormone and glucocorticoids in the bloodstream $[132,133]$. Consequently, orexins are considered crucial regulators of monoaminergic neurotransmission [75]. A recent study shows that the activation of orexin neurons disrupts sleep [134]. The lateral hypothalamus is the most extensively interconnected area of the hypothalamus, allowing it to control diverse autonomic and somatomotor functions. Several studies have revealed direct projections from the lateral hypothalamus to hypothalamic, cortical, and limbic areas [135,136]. These connections are considered to represent the anatomical connectivity that supports sleep-wake regulation $[69,137]$, energy homeostasis, and cognitive functions $[138,139]$. The function of the lateral hypothalamus depends on the function of orexin neurons that produce orexin- $A$ and $-B$ [21]. In an AD animal study, orexin was confirmed to improve memory in mice overproducing amyloid beta [27]. Additionally, treatment with orexin-A and OX1R exerts a neuroprotective effect and improves learning and memory in epilepsy [140]. Hippocampal neurogenesis plays a cardinal role in learning and memory, and the proliferation of immature neurons is particularly important due to their contribution to cognition [141-143]. Orexin-A and its receptors participate in neuronal cell proliferation and developmental mechanisms [144]. Considering upper evidences, we assume that the increase of orexin may improve cognitive impairment following a stroke.

\section{The role of orexin in depression following a stroke}

Depression has considerable implications for the quality of life of affected individuals and is one of the most important causes of early death worldwide $[145,146]$. Depression induces distinctive neuroanatomical changes, including reducing the volume of the hippocampus and prefrontal cortex, which are brain regions that are important for inhibiting the stress response and restricting depressive behavior [147], and enlarging the amygdala [147-151]. Depression results from changes in various biochemical factors, including stress hormones, cytokines, neurotrophic factors such as brain-derived neurotrophic factor (BDNF), and neuropeptides such as orexins [152]. In Parkinson's disease patients with depression, levels of BDNF [153] and orexin [154] are down-regulated. Recently, studies have demonstrated that neuropeptidergic dysregulation plays an essential role in the onset of depressive symptoms $[155,156]$. Since orexin's discovery in 1998, the neuropeptide has been emerging as a promising target against depression [21]. A clinical case regarding the dysregulation of orexin release in depression was reported in 2003 [28].

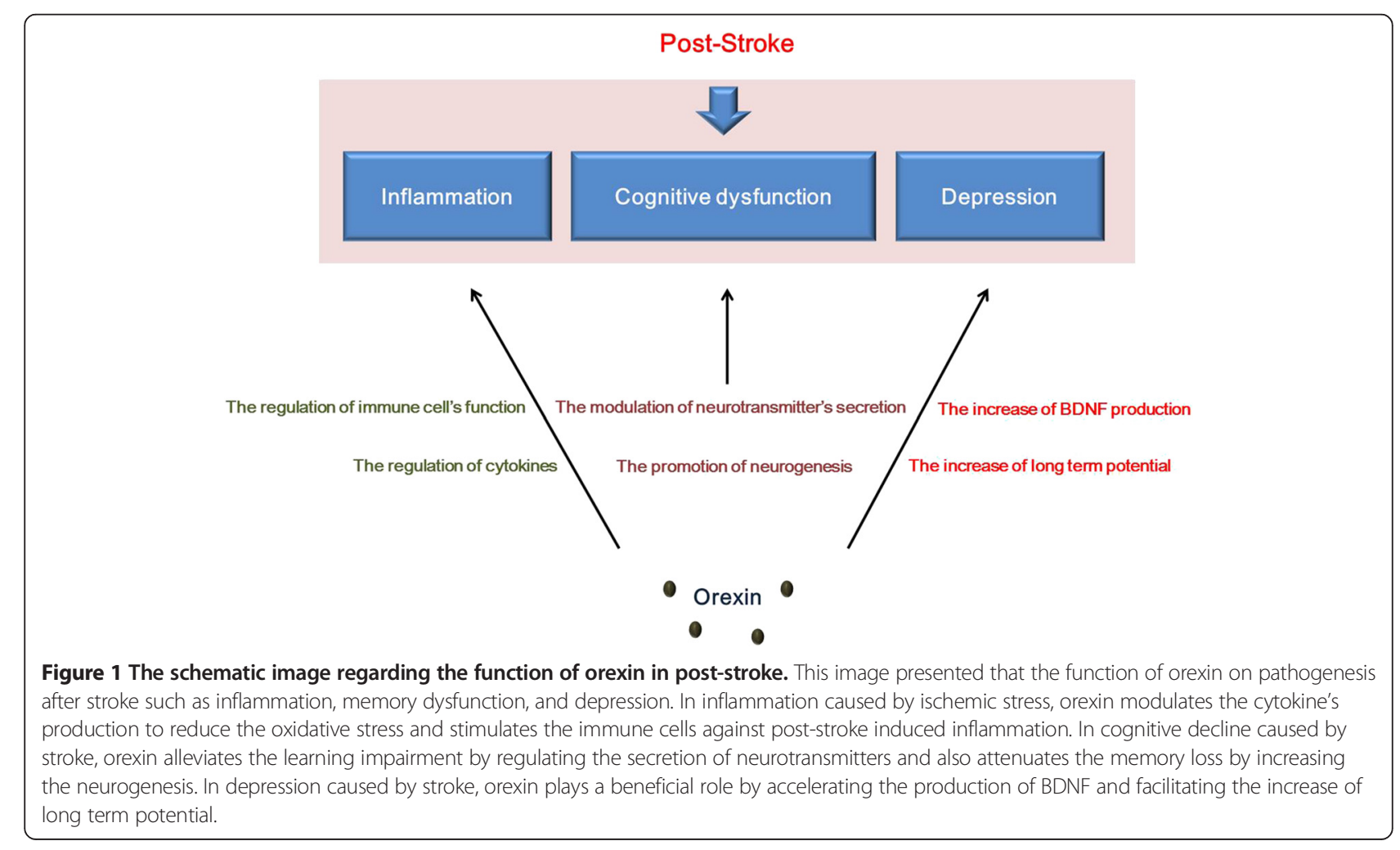


Some suicidal patients show lower levels of orexin A than normal individuals $[157,158]$. Activation of orexin receptors promotes intracellular calcium influx through various intracellular signaling cascades that induce longterm potentiation [149-160]. A relationship between orexinergic neurotransmission and depression has been reported in a genetic rat model of depression [161]. Using orexin receptor knock-out mice, OXR2 was shown to have anti-depressive properties [162]. Specifically, this study showed that mice with increased OXR2 mRNA levels exhibit relatively normal behavior, whereas OXR2 knock-out mice exhibit depressive behavior [162]. In addition, orexin promotes the expression of BDNF $[160,163,164]$, which regulates neuronal plasticity and is reduced in the blood serum of depression patients $[165,166]$. Moreover, an increased concentration of inflammatory cytokines in the brain is the major cause of depression in humans and animals [167-169]. One study showed that the relationship between depression and inflammation is strongly associated with alternations of synaptic plasticity and the metabolism of neurotransmitters involved in mood regulation [170]. Considering these lines of evidence, orexin may be involved in the onset of depression after a stroke. Furthermore, given that orexin regulates the inflammatory response, orexin may attenuate depressive symptoms after a stroke by attenuating inflammation.

\section{Conclusions}

Inflammation, cognitive impairment, and depression are distinctive features that appear after a stroke. To alleviate the pathophysiologies following a stroke, many researchers have studied the regulators of these phenomena. Orexin is a neuropeptide that is known to regulate appetite, metabolism, and sleep/awakeness. In this review, we focused on the emerging roles of orexin in post-stroke-related pathophysiologies. To conclude, this review highlights three remarkable roles of orexin after stroke: 1) orexin controls inflammation by regulating immune mediators such as pro-inflammatory cytokines after stroke; 2) orexin improves memory by modulating other neurotransmitters, and promoting hippocampal neurogenesis, and protecting the neuronal damage against post stroke induced oxidative stress; 3 ) orexin mitigates depression by accelerating neurotrophic factor secretion and by promoting long term potentiation through calcium influx's increase (Figure 1). Although studies concerning the post-stroke role of orexin are still in preliminary stages, further studies involving the function of orexin after stroke might suggest the potential clinical value of orexin as an effective therapeutic modulator to alleviate pathologies following a stroke.

\section{Competing interests}

The authors declare that they have no competing interests.

\section{Authors' contributions}

JS reviewed the studies and wrote the preliminary draft. EK reviewed the concept of studies. C-HK and H-TS revised the manuscript. JEL designed the studies and provided overall supervision of the project. All authors read and approved the final manuscript.

\section{Authors' information}

Juhyun Song (Ph. D) first author.

\section{Acknowledgements}

This study was supported by a grant of the Korean Health Technology R\&D Project, Ministry of Health \& Welfare, Republic of Korea. (HI14C2173).

\section{Author details}

1 Department of Anatomy, Yonsei University College of Medicine, Seoul 120-752, South Korea. ${ }^{2}$ BK21 Plus Project for Medical Sciences, and Brain Research Institute, Yonsei University, College of Medicine, Seoul 120-752, South Korea. ${ }^{3}$ Department of Psychiatry, Yonsei University College of Medicine, 120-752 Seoul, South Korea. ${ }^{4}$ Department of Pharmacology, Yonsei University College of Medicine, 120-752 Seoul, South Korea. ${ }^{5}$ Department of Diagnostic Radiology, Yonsei University College of Medicine, 120-752 Seoul, South Korea.

Received: 15 January 2015 Accepted: 23 February 2015

Published online: 11 March 2015

\section{Reference}

1. Goldstein LB, Bushnell CD, Adams RJ, et al. Guidelines for the primary prevention of stroke: a guideline for healthcare professionals from the American Heart Association/American Stroke Association. Stroke. 2011;42(2):517-84.

2. Strong K, Mathers C, Bonita R. Preventing stroke: saving lives around the world. Lancet Neurol. 2007;6(2):182-7.

3. Li J, Zeng Z, Viollet B, Ronnett GV, McCullough LD. Neuroprotective effects of adenosine monophosphate-activated protein kinase inhibition and gene deletion in stroke. Stroke. 2007;38(11):2992-9.

4. White NW. Capacity building for research: report on a UNION Strategic Planning Workshop. Report of a workshop held during the International Union Against Tuberculosis and Lung Disease World Conference on Lung Health, Montreal, Canada, 7 October 2002. Int J Tuberc Lung Dis. 2004;8(7):910-4.

5. Ezzati M, Hoorn SV, Lopez AD, et al. Comparative Quantification of Mortality and Burden of Disease Attributable to Selected Risk Factors. In: Lopez AD, Mathers CD, Ezzati M, Jamison DT, Murray CJL, editors. Global Burden of Disease and Risk Factors. Washington (DC): World Bank; 2006.

6. Feigin VL, Lawes CM, Bennett DA, Anderson CS. Stroke epidemiology: a review of population-based studies of incidence, prevalence, and case-fatality in the late 20th century. Lancet Neurol. 2003;2(1):43-53.

7. Kernan WN, Viscoli CM, Inzucchi SE, Brass LM, Bravata DM, Shulman Gl, et al. Prevalence of abnormal glucose tolerance following a transient ischemic attack or ischemic stroke. Arch Intern Med. 2005;165(2):227-33.

8. Dietrich WD, Alonso O, Busto R. Moderate hyperglycemia worsens acute blood-brain barrier injury after forebrain ischemia in rats. Stroke. 1993;24(1):111-6.

9. Tatemichi TK, Desmond DW, Mayeux R, Paik M, Stern Y, Sano M, et al. Dementia after stroke: baseline frequency, risks, and clinical features in a hospitalized cohort. Neurology. 1992;42(6):1185-93.

10. Tatemichi TK, Paik M, Bagiella E, Desmond DW, Stern Y, Sano M, et al. Risk of dementia after stroke in a hospitalized cohort: results of a longitudinal study. Neurology. 1994;44(10):1885-91.

11. Tatemichi TK, Foulkes MA, Mohr JP, Hewitt JR, Hier DB, Price TR, et al. Dementia in stroke survivors in the Stroke Data Bank cohort. Prevalence, incidence, risk factors, and computed tomographic findings. Stroke. 1990;21(6):858-66.

12. Ayerbe L, Ayis S, Wolfe CD, Rudd AG. Natural history, predictors and outcomes of depression after stroke: systematic review and meta-analysis. Br J Psychiatry. 2013;202(1):14-21. 
13. Paolucci S. Epidemiology and treatment of post-stroke depression. Neuropsychiatr Dis Treat. 2008;4(1):145-54.

14. House A, Dennis M, Warlow C, Hawton K, Molyneux A. Mood disorders after stroke and their relation to lesion location. A CT scan study. Brain. 1990;113(Pt 4):1113-29.

15. Gray WP, Sundstrom LE. Kainic acid increases the proliferation of granule cell progenitors in the dentate gyrus of the adult rat. Brain Res. 1998;790(1-2):52-9.

16. Sakurai T. Roles of orexin/hypocretin in regulation of sleep/wakefulness and energy homeostasis. Sleep Med Rev. 2005:9(4):231-41.

17. Sutcliffe JG, de Lecea L. The hypocretins: excitatory neuromodulatory peptides for multiple homeostatic systems, including sleep and feeding. J Neurosci Res. 2000;62(2):161-8.

18. Yokobori E, Kojima K, Azuma M, Kang KS, Maejima S, Uchiyama M, et al. Stimulatory effect of intracerebroventricular administration of orexin $A$ on food intake in the zebrafish, Danio rerio. Peptides. 2011;32(7):1357-62.

19. Trivedi $P, Y u$ H, MacNeil DJ, Van der Ploeg LH, Guan XM. Distribution of orexin receptor mRNA in the rat brain. FEBS Lett. 1998;438(1-2):71-5.

20. Marcus JN, Aschkenasi CJ, Lee CE, Chemelli RM, Saper CB, Yanagisawa M, et al. Differential expression of orexin receptors 1 and 2 in the rat brain. J Comp Neurol. 2001;435(1):6-25.

21. de Lecea L, Kilduff TS, Peyron C, Gao X, Foye PE, Danielson PE, et al. The hypocretins: hypothalamus-specific peptides with neuroexcitatory activity. Proc Natl Acad Sci U S A. 1998;95(1):322-7.

22. Eichenbaum H, Otto T, Cohen NJ. The hippocampus-what does it do? Behav Neural Biol. 1992;57(1):2-36.

23. Jarrard LE. On the role of the hippocampus in learning and memory in the rat. Behav Neural Biol. 1993;60(1):9-26

24. Li A, Hindmarch CC, Nattie EE, Paton JF. Antagonism of orexin receptors significantly lowers blood pressure in spontaneously hypertensive rats. J Physiol. 2013;591 (Pt 17):4237-48

25. Butterick TA, Nixon JP, Billington CJ, Kotz CM. Orexin A decreases lipid peroxidation and apoptosis in a novel hypothalamic cell model. Neurosci Lett. 2012:524(1):30-4.

26. Akbari E, Naghdi N, Motamedi F. The selective orexin 1 receptor antagonist SB-334867-A impairs acquisition and consolidation but not retrieval of spatial memory in Morris water maze. Peptides. 2007;28(3):650-6.

27. Jaeger LB, Farr SA, Banks WA, Morley JE. Effects of orexin-A on memory processing. Peptides. 2002;23(9):1683-8.

28. Salomon RM, Ripley B, Kennedy JS, Johnson B, Schmidt D, Zeitzer JM, et al. Diurnal variation of cerebrospinal fluid hypocretin-1 (Orexin-A) levels in control and depressed subjects. Biol Psychiatry. 2003:54(2):96-104.

29. ladecola C, Anrather J. The immunology of stroke: from mechanisms to translation. Nat Med. 2011;17(7):796-808

30. Moskowitz MA, Lo EH, ladecola C. The science of stroke: mechanisms in search of treatments. Neuron. 2010;67(2):181-98.

31. ladecola C, Kahles T, Gallo EF, Anrather J. Neurovascular protection by ischaemic tolerance: role of nitric oxide. J Physiol. 2011;589(Pt 17):4137-45.

32. Dirnagl U, ladecola C, Moskowitz MA. Pathobiology of ischaemic stroke: an integrated view. Trends Neurosci. 1999;22(9):391-7.

33. Lo EH. Degeneration and repair in central nervous system disease. Nat Med. 2010;16(11):1205-9.

34. Abe T, Shimamura M, Jackman K, Kurinami H, Anrather J, Zhou P, et al. Key role of CD36 in Toll-like receptor 2 signaling in cerebral ischemia. Stroke. 2010:41(5):898-904.

35. Shichita T, Ito M, Yoshimura A. Post-ischemic inflammation regulates neural damage and protection. Front Cell Neurosci. 2014;8:319.

36. Stoll $\mathrm{G}$, Jander $\mathrm{S}$, Schroeter $\mathrm{M}$. Inflammation and glial responses in ischemic brain lesions. Prog Neurobiol. 1998;56(2):149-71.

37. Pendlebury ST. Stroke-related dementia: rates, risk factors and implications for future research. Maturitas. 2009;64(3):165-71.

38. Erkinjuntti T. Diagnosis and management of vascular cognitive impairment and dementia. J Neural Transm Suppl. 2002; (63):91-109.

39. Cordonnier C, Henon H, Derambure P, Pasquier F, Leys D. Influence of pre-existing dementia on the risk of post-stroke epileptic seizures. J Neurol Neurosurg Psychiatry. 2005;76(12):1649-53.

40. Leys D, Henon H, Mackowiak-Cordoliani MA, Pasquier F. Poststroke dementia. Lancet Neurol. 2005:4(11):752-9.

41. Borson S, Frank L, Bayley PJ, Boustani M, Dean M, Lin PJ, et al. Improving dementia care: the role of screening and detection of cognitive impairment. Alzheimers Dement. 2013:9(2):151-9.
42. D'Esposito M. Working memory. Handb Clin Neurol. 2008;88:237-47.

43. Cullen B, O'Neill B, Evans JJ, Coen RF, Lawlor BA. A review of screening tests for cognitive impairment. J Neurol Neurosurg Psychiatry. 2007;78(8):790-9.

44. Desmond DW, Moroney JT, Paik MC, Sano M, Mohr JP, Aboumatar S, et al. Frequency and clinical determinants of dementia after ischemic stroke. Neurology. 2000;54(5):1124-31.

45. Nys GM, van Zandvoort MJ, de Kort PL, Jansen BP, Kappelle LJ, de Haan EH. Restrictions of the Mini-Mental State Examination in acute stroke. Arch Clin Neuropsychol. 2005;20(5):623-9.

46. Jacquin A, Binquet C, Rouaud O, Graule-Petot A, Daubail B, Osseby GV, et al. Post-stroke cognitive impairment: high prevalence and determining factors in a cohort of mild stroke. J Alzheimers Dis. 2014;40(4):1029-38.

47. Li W, Huang R, Shetty RA, Thangthaeng N, Liu R, Chen Z, et al. Transient focal cerebral ischemia induces long-term cognitive function deficit in an experimental ischemic stroke model. Neurobiol Dis. 2013;59:18-25.

48. Wen X, Qi D, Sun Y, Huang X, Zhang F, Wu J, et al. H(2)S attenuates cognitive deficits through Akt1/JNK3 signaling pathway in ischemic stroke. Behav Brain Res. 2014;269:6-14.

49. Loubinoux I, Kronenberg G, Endres M, Schumann-Bard P, Freret T, Filipkowski RK, et al. Post-stroke depression: mechanisms, translation and therapy. J Cell Mol Med. 2012:16(9):1961-9.

50. Robinson RG, Price TR. Post-stroke depressive disorders: a follow-up study of 103 patients. Stroke. 1982;13(5):635-41.

51. Folstein MF, Maiberger R, McHugh PR. Mood disorder as a specific complication of stroke. J Neurol Neurosurg Psychiatry. 1977:40(10):1018-20.

52. Robinson RG, Shoemaker WJ, Schlumpf M, Valk T, Bloom FE. Effect of experimental cerebral infarction in rat brain on catecholamines and behaviour. Nature 1975:255(5506):332-4.

53. Hackett ML, Yapa C, Parag V, Anderson CS. Frequency of depression after stroke: a systematic review of observational studies. Stroke. 2005;36(6):1330-40.

54. Cousins R. Prosopagnosia after stroke: potentials for impairment and treatment. Top Stroke Rehabil. 2013;20(6):471-7.

55. Jeong YJ, Kim WC, Kim YS, Choi KW, Son SY, Jeong YG. The Relationship between Rehabilitation and Changes in Depression in Stroke Patients. J Phys Ther Sci. 2014;26(8):1263-6.

56. Mpembi MN, Miezi SM, Nzuzi TM, Massamba VK, Henrard S, De Partz MP, et al. [Clinical profile of post-cerebrovascular depression: descriptive cross-sectional study in the rehabilitation center for people with disabilities of Kinshasa (DR Congo)]. Pan Afr Med J. 2014;17:109.

57. Murata $Y$, Kimura M, Robinson RG. Does cognitive impairment cause post-stroke depression? Am J Geriatr Psychiatry. 2000;8(4):310-7.

58. Sakurai T, Amemiya A, Ishii M, Matsuzaki I, Chemelli RM, Tanaka H, et al. Orexins and orexin receptors: a family of hypothalamic neuropeptides and $\mathrm{G}$ protein-coupled receptors that regulate feeding behavior. Cell. 1998;92(4):573-85.

59. Sakurai T. The neural circuit of orexin (hypocretin): maintaining sleep and wakefulness. Nat Rev Neurosci. 2007:8(3):171-81.

60. Carter ME, Schaich Borg J, de Lecea L. The brain hypocretins and their receptors: mediators of allostatic arousal. Curr Opin Pharmacol. 2009;9(1):39-45.

61. Barinaga M. New appetite-boosting peptides found. Science. 1998:279 (5354):1134.

62. Wolf G. Orexins: a newly discovered family of hypothalamic regulators of food intake. Nutr Rev. 1998;56(6):172-3.

63. Yamanaka A, Tabuchi S, Tsunematsu T, Fukazawa Y, Tominaga M. Orexin directly excites orexin neurons through orexin 2 receptor. J Neurosci. 2010:30(38):12642-52.

64. van den Pol AN, Gao XB, Patrylo PR, Ghosh PK, Obrietan K. Glutamate inhibits GABA excitatory activity in developing neurons. J Neurosci. 1998;18(24):10749-61.

65. Belle MD, Hughes AT, Bechtold DA, Cunningham P, Pierucci M, Burdakov D, et al. Acute suppressive and long-term phase modulation actions of orexin on the mammalian circadian clock. J Neurosci. 2014;34(10):3607-21.

66. Li Y, Gao XB, Sakurai T, van den Pol AN. Hypocretin/Orexin excites hypocretin neurons via a local glutamate neuron-A potential mechanism for orchestrating the hypothalamic arousal system. Neuron. 2002:36(6):1169-81.

67. Kastin AJ, Akerstrom V. Orexin A but not orexin B rapidly enters brain from blood by simple diffusion. J Pharmacol Exp Ther. 1999;289(1):219-23.

68. Gotter AL, Webber AL, Coleman PJ, Renger JJ, Winrow CJ. International Union of Basic and Clinical Pharmacology. LXXXVI. Orexin receptor function, nomenclature and pharmacology. Pharmacol Rev. 2012;64(3):389-420. 
69. Peyron C, Tighe DK, van den Pol AN, de Lecea L, Heller HC, Sutcliffe JG, et al. Neurons containing hypocretin (orexin) project to multiple neuronal systems. J Neurosci. 1998;18(23):9996-10015

70. Armitage R. Sleep and circadian rhythms in mood disorders. Acta Psychiatr Scand Suppl 2007; (433):104-15. doi:10.1111/j.1600-0447.2007.00968.x.

71. Steiger A, Kimura M. Wake and sleep EEG provide biomarkers in depression. J Psychiatr Res. 2010;44(4):242-52.

72. Luppino FS, de Wit LM, Bouvy PF, Stijnen T, Cuijpers P, Penninx BW, et al Overweight, obesity, and depression: a systematic review and meta-analysis of longitudinal studies. Arch Gen Psychiatry. 2010;67(3):220-9.

73. Stunkard AJ, Faith MS, Allison KC. Depression and obesity. Biol Psychiatry. 2003;54(3):330-7

74. Dube MG, Kalra SP, Kalra PS. Food intake elicited by central administration of orexins/hypocretins: identification of hypothalamic sites of action. Brain Res. 1999;842(2):473-7.

75. Sakurai T, Mieda M. Connectomics of orexin-producing neurons: interface of systems of emotion, energy homeostasis and arousal. Trends Pharmacol Sci. 2011;32(8):451-62.

76. Moriguchi T, Sakurai T, Nambu T, Yanagisawa M, Goto K. Neurons containing orexin in the lateral hypothalamic area of the adult rat brain are activated by insulin-induced acute hypoglycemia. Neurosci Lett. 1999;264(1-3):101-4.

77. Yamanaka A, Beuckmann CT, Willie JT, Hara J, Tsujino N, Mieda M, et al. Hypothalamic orexin neurons regulate arousal according to energy balance in mice. Neuron. 2003;38(5):701-13.

78. Burdakov D, Gerasimenko O, Verkhratsky A. Physiological changes in glucose differentially modulate the excitability of hypothalamic melanin-concentrating hormone and orexin neurons in situ. J Neurosci. 2005;25(9):2429-33.

79. Karnani M, Burdakov D. Multiple hypothalamic circuits sense and regulate glucose levels. Am J Physiol Regul Integr Comp Physiol. 2011;300(1):R47-55.

80. Tsuneki H, Wada T, Sasaoka T. Role of orexin in the regulation of glucose homeostasis. Acta Physiol (Oxf). 2010;198(3):335-48.

81. Karnani MM, Apergis-Schoute J, Adamantidis A, Jensen LT, de Lecea L, Fugger $L$, et al. Activation of central orexin/hypocretin neurons by dietary amino acids. Neuron. 2011;72(4):616-29.

82. Williams RH, Jensen LT, Verkhratsky A, Fugger L, Burdakov D. Control of hypothalamic orexin neurons by acid and CO2. Proc Natl Acad Sci U S A. 2007;104(25):10685-90.

83. Sakurai $T$, Nagata $R$, Yamanaka A, Kawamura $H$, Tsujino N, Muraki $Y$, et al. Input of orexin/hypocretin neurons revealed by a genetically encoded tracer in mice. Neuron. 2005;46(2):297-308.

84. Samson WK, Gosnell B, Chang JK, Resch ZT, Murphy TC. Cardiovascular regulatory actions of the hypocretins in brain. Brain Res. 1999;831(1-2):248-53.

85. Shirasaka T, Nakazato M, Matsukura S, Takasaki M, Kannan H. Sympathetic and cardiovascular actions of orexins in conscious rats. Am J Physiol. 1999;277(6 Pt 2):R1780-5.

86. Chen CT, Hwang LL, Chang JK, Dun NJ. Pressor effects of orexins injected intracisternally and to rostral ventrolateral medulla of anesthetized rats. Am J Physiol Regul Integr Comp Physiol. 2000;278(3):R692-7.

87. Dun NJ, Le Dun S, Chen CT, Hwang LL, Kwok EH, Chang JK. Orexins: a role in medullary sympathetic outflow. Regul Pept. 2000;96(1-2):65-70.

88. Kayaba Y, Nakamura A, Kasuya Y, Ohuchi T, Yanagisawa M, Komuro I, et al. Attenuated defense response and low basal blood pressure in orexin knockout mice. Am J Physiol Regul Integr Comp Physiol. 2003;285(3):R581-93.

89. Marazziti D, Consoli G, Picchetti M, Carlini M, Faravelli L. Cognitive impairment in major depression. Eur J Pharmacol. 2010;626(1):83-6.

90. Murrough JW, lacoviello B, Neumeister A, Charney DS, losifescu DV. Cognitive dysfunction in depression: neurocircuitry and new therapeutic strategies. Neurobiol Learn Mem. 2011;96(4):553-63.

91. Telegdy $G$, Adamik $A$. The action of orexin A on passive avoidance learning. Involvement of transmitters. Regul Pept. 2002;104(1-3):105-10.

92. Yang L, Zou B, Xiong X, Pascual C, Xie J, Malik A, et al. Hypocretin/orexin neurons contribute to hippocampus-dependent social memory and synaptic plasticity in mice. J Neurosci. 2013;33(12):5275-84.

93. Rejdak K, Papuc E, Grieb P, Stelmasiak Z. Decreased cerebrospinal fluid hypocretin-1 (orexin A) in patients after repetitive generalized tonic-clonic seizures. Epilepsia. 2009;50(6):1641-4.

94. Lin J, Yan G, Gao X, Liao J, Hao X, Zhang K. Effect of intestinal ischemia/ reperfusion injury on leptin and orexin-A levels. Front Med China. 2007;1(1):87-92
95. Kotan D, Deniz O, Aygul R, Yildirim A. Acute cerebral ischaemia: relationship between serum and cerebrospinal fluid orexin-A concentration and infarct volume. J Int Med Res. 2013;41(2):404-9.

96. Messina G, Dalia C, Tafuri D, Monda V, Palmieri F, Dato A, et al. Orexin-A controls sympathetic activity and eating behavior. Front Psychol. 2014;5:997.

97. Clifford L, Dampney BW, Carrive P. Spontaneously hypertensive rats have more orexin neurons in their medial hypothalamus than normotensive rats. Exp Physiol 2015. doi:10.1113/expphysiol.2014.084137.

98. Li A, Nattie E. Orexin, cardio-respiratory function, and hypertension. Front Neurosci. 2014:8:22.

99. Lee YH, Dai YW, Huang SC, Li TL, Hwang LL. Blockade of central orexin 2 receptors reduces arterial pressure in spontaneously hypertensive rats. Exp Physiol. 2013;98(7):1145-55

100. Matsumura K, Tsuchihashi T, Fujii K, lida M. Neural regulation of blood pressure by leptin and the related peptides. Regul Pept. 2003;114(2-3):79-86.

101. Shirasaka T, Takasaki M, Kannan H. Cardiovascular effects of leptin and orexins. Am J Physiol Regul Integr Comp Physiol. 2003;284(3):R639-51.

102. Huang SC, Dai YW, Lee YH, Chiou LC, Hwang LL. Orexins depolarize rostral ventrolateral medulla neurons and increase arterial pressure and heart rate in rats mainly via orexin 2 receptors. J Pharmacol Exp Ther. 2010;334(2):522-9.

103. Shahid IZ, Rahman AA, Pilowsky PM. Orexin A in rat rostral ventrolateral medulla is pressor, sympatho-excitatory, increases barosensitivity and attenuates the somato-sympathetic reflex. Br J Pharmacol. 2012;165(7):2292-303.

104. Brisbare-Roch C, Dingemanse J, Koberstein R, Hoever P, Aissaoui H, Flores S, et al. Promotion of sleep by targeting the orexin system in rats, dogs and humans. Nat Med. 2007;13(2):150-5

105. Matsumura K, Tsuchihashi T, Abe I. Central orexin-A augments sympathoadrenal outflow in conscious rabbits. Hypertension. 2001;37(6):1382-7.

106. Bulbul M, Tan R, Gemici B, Ongut G, Izgut-Uysal VN. Effect of orexin-a on ischemia-reperfusion-induced gastric damage in rats. J Gastroenterol. 2008;43(3):202-7.

107. Gorgui J, Gorshkov M, Khan N, Daskalopoulou SS. Hypertension as a risk factor for ischemic stroke in women. Can J Cardiol. 2014;30(7):774-82.

108. Lin PH, Yeh WT, Svetkey LP, Chuang SY, Chang YC, Wang C, et al. Dietary intakes consistent with the DASH dietary pattern reduce blood pressure increase with age and risk for stroke in a Chinese population. Asia Pac J Clin Nutr. 2013;22(2):482-91.

109. Wang IK, Chang SN, Liao CC, Liang CC, Chang CT, Lin HH, et al. Hypertensive disorders in pregnancy and preterm delivery and subsequent stroke in Asian women: a retrospective cohort study. Stroke. 2011;42(3):716-21.

110. Harada S, Fujita-Hamabe W, Tokuyama S. Effect of orexin-A on post-ischemic glucose intolerance and neuronal damage. J Pharmacol Sci. 2011;115(2):155-63.

111. Gerashchenko D, Shiromani PJ. Effects of inflammation produced by chronic lipopolysaccharide administration on the survival of hypocretin neurons and sleep. Brain Res. 2004;1019(1-2):162-9.

112. Clark IA, Vissel B. Inflammation-sleep interface in brain disease: TNF, insulin, orexin. J Neuroinflammation. 2014;11:51

113. Xiong $X$, White $R E$, $X u L$, Yang $L$, Sun $X$, Zou B, et al. Mitigation of murine focal cerebral ischemia by the hypocretin/orexin system is associated with reduced inflammation. Stroke. 2013;44(3):764-70.

114. Yan GT, Lin J, Liao J. [Distribution of Orexin-A mRNA expression in different organs and its variation in acute inflammation]. Zhongguo Wei Zhong Bing Ji Jiu Yi Xue. 2005;17(4):207-10.

115. Ammoun S, Holmqvist T, Shariatmadari R, Oonk HB, Detheux M, Parmentier $M$, et al. Distinct recognition of $O X 1$ and $O X 2$ receptors by orexin peptides. J Pharmacol Exp Ther. 2003;305(2):507-14

116. Ammoun S, Johansson L, Ekholm ME, Holmqvist T, Danis AS, Korhonen L, et al. OX1 orexin receptors activate extracellular signal-regulated kinase in Chinese hamster ovary cells via multiple mechanisms: the role of $\mathrm{Ca} 2+$ influx in OX1 receptor signaling. Mol Endocrinol. 2006;20(1):80-99.

117. Ramanjaneya M, Conner AC, Chen J, Kumar P, Brown JE, Johren $\mathrm{O}$, et al. Orexin-stimulated MAP kinase cascades are activated through multiple G-protein signalling pathways in human H295R adrenocortical cells: diverse roles for orexins A and B. J Endocrinol. 2009;202(2):249-61.

118. Zhan S, Cai GQ, Zheng A, Wang Y, Jia J, Fang H, et al. Tumor necrosis factor-alpha regulates the Hypocretin system via mRNA degradation and ubiquitination. Biochim Biophys Acta. 2011;1812(4):565-71.

119. Kitamura E, Hamada J, Kanazawa N, Yonekura J, Masuda R, Sakai F, et al. The effect of orexin-A on the pathological mechanism in the rat focal cerebral ischemia. Neurosci Res. 2010;68(2):154-7. 
120. Yuan LB, Dong HL, Zhang HP, Zhao RN, Gong G, Chen XM, et al. Neuroprotective effect of orexin-A is mediated by an increase of hypoxia-inducible factor-1 activity in rat. Anesthesiology. 2011;114(2):340-54.

121. Sikder $D$, Kodadek T. The neurohormone orexin stimulates hypoxia-inducible factor-1 activity. Genes Dev. 2007;21(22):2995-3005.

122. Sokolowska P, Urbanska A, Namiecinska M, Bieganska K, Zawilska JB. Orexins promote survival of rat cortical neurons. Neurosci Lett. 2012;506(2):303-6.

123. Dauvilliers Y. Follow-up of four narcolepsy patients treated with intravenous immunoglobulins. Ann Neurol. 2006;60(1):153.

124. Cvetkovic-Lopes V, Bayer L, Dorsaz S, Maret S, Pradervand S, Dauvilliers Y, et al. Elevated Tribbles homolog 2-specific antibody levels in narcolepsy patients. J Clin Invest. 2010;120(3):713-9.

125. Toyoda H, Tanaka S, Miyagawa T, Honda Y, Tokunaga K, Honda M. Anti-Tribbles homolog 2 autoantibodies in Japanese patients with narcolepsy. Sleep. 2010;33(7):875-8.

126. Peyron C, Faraco J, Rogers W, Ripley B, Overeem S, Charnay Y, et al. A mutation in a case of early onset narcolepsy and a generalized absence of hypocretin peptides in human narcoleptic brains. Nat Med. 2000;6(9):991-7.

127. Thannickal TC, Moore RY, Nienhuis R, Ramanathan L, Gulyani S, Aldrich M, et al. Reduced number of hypocretin neurons in human narcolepsy. Neuron. 2000;27(3):469-74.

128. Himmerich H, Beitinger PA, Fulda S, Wehrle R, Linseisen J, Wolfram G, et al. Plasma levels of tumor necrosis factor alpha and soluble tumor necrosis factor receptors in patients with narcolepsy. Arch Intern Med. 2006;166(16):1739-43.

129. Deadwyler SA, Porrino L, Siegel JM, Hampson RE. Systemic and nasal delivery of orexin-A (Hypocretin-1) reduces the effects of sleep deprivation on cognitive performance in nonhuman primates. J Neurosci. 2007;27(52):14239-47.

130. Akbari E, Motamedi F, Naghdi N, Noorbakhshnia M. The effect of antagonization of orexin 1 receptors in $\mathrm{CA} 1$ and dentate gyrus regions on memory processing in passive avoidance task. Behav Brain Res. 2008;187(1):172-7.

131. Akbari E, Naghdi N, Motamedi F. Functional inactivation of orexin 1 receptors in $\mathrm{CA} 1$ region impairs acquisition, consolidation and retrieval in Morris water maze task. Behav Brain Res. 2006:173(1):47-52.

132. Lopez M, Tena-Sempere M, Dieguez C. Cross-talk between orexins (hypocretins) and the neuroendocrine axes (hypothalamic-pituitary axes). Front Neuroendocrinol. 2010;31(2):113-27.

133. Spinazzi R, Andreis PG, Rossi GP, Nussdorfer GG. Orexins in the regulation of the hypothalamic-pituitary-adrenal axis. Pharmacol Rev. 2006;58(1):46-57.

134. Rolls A, Colas D, Adamantidis A, Carter M, Lanre-Amos T, Heller HC, et al. Optogenetic disruption of sleep continuity impairs memory consolidation. Proc Natl Acad Sci U S A. 2011;108(32):13305-10.

135. Saper CB. Organization of cerebral cortical afferent systems in the rat. II. Hypothalamocortical projections. J Comp Neurol. 1985;237(1):21-46.

136. Saper CB, Akil H, Watson SJ. Lateral hypothalamic innervation of the cerebral cortex: immunoreactive staining for a peptide resembling but immunochemically distinct from pituitary/arcuate alpha-melanocyte stimulating hormone. Brain Res Bull. 1986;16(1):107-20.

137. Bittencourt JC, Presse F, Arias C, Peto C, Vaughan J, Nahon JL, et al. The melanin-concentrating hormone system of the rat brain: an immuno- and hybridization histochemical characterization. J Comp Neurol. 1992;319(2):218-45.

138. Berthoud HR. Multiple neural systems controlling food intake and body weight. Neurosci Biobehav Rev. 2002;26(4):393-428.

139. Saper CB, Chou TC, Elmquist JK. The need to feed: homeostatic and hedonic control of eating. Neuron. 2002;36(2):199-211.

140. Zhao X, Zhang R, Tang S, Ren Y, Yang W, Liu X, et al. Orexin-A-induced ERK1/2 activation reverses impaired spatial learning and memory in pentylenetetrazol-kindled rats via OX1R-mediated hippocampal neurogenesis. Peptides. 2014;54:140-7.

141. Coras R, Siebzehnrubl FA, Pauli E, Huttner HB, Njunting M, Kobow K, et al. Low proliferation and differentiation capacities of adult hippocampal stem cells correlate with memory dysfunction in humans. Brain. 2010;133(11):3359-72

142. Deng W, Saxe MD, Gallina IS, Gage FH. Adult-born hippocampal dentate granule cells undergoing maturation modulate learning and memory in the brain. J Neurosci. 2009;29(43):13532-42.

143. Jessberger S, Clark RE, Broadbent NJ, Clemenson Jr GD, Consiglio A, Lie DC, et al. Dentate gyrus-specific knockdown of adult neurogenesis impairs spatial and object recognition memory in adult rats. Learn Mem. 2009;16(2):147-54.

144. Kim MK, Park HJ, Kim SR, Choi YK, Shin HK, Jeon JH, et al. Angiogenic role of orexin-A via the activation of extracellular signal-regulated kinase in endothelial cells. Biochem Biophys Res Commun. 2010;403(1):59-65.

145. Mathers CD, Loncar D. Projections of global mortality and burden of disease from 2002 to 2030. PLoS Med. 2006;3(11):e442.

146. Murray CJ, Lopez AD. Alternative projections of mortality and disability by cause 1990-2020: Global Burden of Disease Study. Lancet. 1997;349(9064):1498-504.

147. MacQueen G, Frodl T. The hippocampus in major depression: evidence for the convergence of the bench and bedside in psychiatric research? Mol Psychiatry. 2011;16(3):252-64.

148. Krishnan V, Nestler EJ. Linking molecules to mood: new insight into the biology of depression. Am J Psychiatry. 2010;167(11):1305-20.

149. Pittenger C, Duman RS. Stress, depression, and neuroplasticity: a convergence of mechanisms. Neuropsychopharmacology. 2008;33(1):88-109.

150. Holderbach R, Clark K, Moreau JL, Bischofberger J, Normann C. Enhanced long-term synaptic depression in an animal model of depression. Biol Psychiatry. 2007;62(1):92-100.

151. McKinnon MC, Yucel K, Nazarov A, MacQueen GM. A meta-analysis examining clinical predictors of hippocampal volume in patients with major depressive disorder. J Psychiatry Neurosci. 2009;34(1):41-54.

152. Belmaker RH, Agam G. Major depressive disorder. N Engl J Med. 2008;358(1):55-68

153. Zhang J, Sokal I, Peskind ER, Quinn JF, Jankovic J, Kenney C, et al. CSF multianalyte profile distinguishes Alzheimer and Parkinson diseases. Am J Clin Pathol. 2008;129(4):526-9.

154. Drouot X, Moutereau S, Nguyen JP, Lefaucheur JP, Creange A, Remy P, et al. Low levels of ventricular CSF orexin/hypocretin in advanced PD. Neurology. 2003;61(4):540-3.

155. Belzung C, Yalcin I, Griebel G, Surget A, Leman S. Neuropeptides in psychiatric diseases: an overview with a particular focus on depression and anxiety disorders. CNS Neurol Disord Drug Targets. 2006;5(2):135-45.

156. Rotzinger S, Lovejoy DA, Tan LA. Behavioral effects of neuropeptides in rodent models of depression and anxiety. Peptides. 2010;31(4):736-56.

157. Brundin L, Bjorkqvist M, Traskman-Bendz L, Petersen A. Increased orexin levels in the cerebrospinal fluid the first year after a suicide attempt. J Affect Disord. 2009;113(1-2):179-82

158. Palhagen S, Qi H, Martensson B, Walinder J, Granerus AK, Svenningsson P, et al. IL-6 and corticosterone in CSF in patients with Parkinson's disease and major depression. J Neurol. 2010;257(4):524-32.

159. Holmqvist $T$, Johansson L, Ostman M, Ammoun S, Akerman KE, Kukkonen JP. OX1 orexin receptors couple to adenylyl cyclase regulation via multiple mechanisms. J Biol Chem. 2005;280(8):6570-9.

160. Lund PE, Shariatmadari R, Uustare A, Detheux M, Parmentier M, Kukkonen $J P$, et al. The orexin OX1 receptor activates a novel Ca2+ influx pathway necessary for coupling to phospholipase C. J Biol Chem. 2000;275(40):30806-12.

161. Allard JS, Tizabi Y, Shaffery JP, Trouth CO, Manaye K. Stereological analysis of the hypothalamic hypocretin/orexin neurons in an animal model of depression. Neuropeptides. 2004;38(5):311-5.

162. Scott MM, Marcus JN, Pettersen A, Birnbaum SG, Mochizuki T, Scammell TE, et al. Hcrtr1 and 2 signaling differentially regulates depression-like behaviors. Behav Brain Res. 2011;222(2):289-94

163. Akbari E, Motamedi F, Davoodi FG, Noorbakhshnia M, Ghanbarian E. Orexin-1 receptor mediates long-term potentiation in the dentate gyrus area of freely moving rats. Behav Brain Res. 2011;216(1):375-80.

164. Yamada N, Katsuura G, Tatsuno I, Kawahara S, Ebihara K, Saito Y, et al. Orexins increase mRNA expressions of neurotrophin-3 in rat primary cortical neuron cultures. Neurosci Lett. 2009;450(2):132-5.

165. Post RM. Role of BDNF in bipolar and unipolar disorder: clinical and theoretical implications. J Psychiatr Res. 2007;41(12):979-90.

166. Nestler EJ, Carlezon Jr WA. The mesolimbic dopamine reward circuit in depression. Biol Psychiatry. 2006;59(12):1151-9.

167. Dean B, Tawadros N, Scarr E, Gibbons AS. Regionally-specific changes in levels of tumour necrosis factor in the dorsolateral prefrontal cortex obtained postmortem from subjects with major depressive disorder. J Affect Disord. 2010;120(1-3):245-8.

168. Goshen I, Kreisel T, Ben-Menachem-Zidon O, et al. Brain interleukin-1 mediates chronic stress-induced depression in mice via adrenocortical 
activation and hippocampal neurogenesis suppression. Mol Psychiatry. 2008;13(7):717-28.

169. Himmerich H, Fulda S, Linseisen J, Seiler H, Wolfram G, Himmerich S, et al. Depression, comorbidities and the TNF-alpha system. Eur Psychiatry. 2008;23(6):421-9.

170. Khairova RA, Machado-Vieira R, Du J, Manji HK. A potential role for pro-inflammatory cytokines in regulating synaptic plasticity in major depressive disorder. Int J Neuropsychopharmacol. 2009;12(4):561-78.

Submit your next manuscript to BioMed Central and take full advantage of:

- Convenient online submission

- Thorough peer review

- No space constraints or color figure charges

- Immediate publication on acceptance

- Inclusion in PubMed, CAS, Scopus and Google Scholar

- Research which is freely available for redistribution 